\title{
Skrining Penyakit Menular Pada Ibu Hamil di Rumah Sakit Umum Daerah Kwaingga Kabupaten Keerom
}

\author{
Rini Prastyawati ${ }^{1}$, Tika Romadhonni ${ }^{2}$, Thiara Pradasari $^{3}$ \\ ${ }^{12}$ Dosen Prodi Analis Kesehatan, Universitas Sains dan Teknologi Jayapura, Indonesia \\ ${ }^{3}$ Analis Kesehatan FIKES USTJ
}

\section{Article Info \\ Article history: \\ Received Aug 03 ${ }^{\text {th }}, 2020$ \\ Revised Jan $31^{\text {th }}, 2021$ \\ Accepted Feb 18 ${ }^{\text {th }}, 2021$}

\section{Keyword:}

Keywords:

Pregnant women, $H$ epatitis $B$,

Syphilis

\begin{abstract}
A research entitled Infectious Disease Screening for Pregnant Women at the Kwaingga, Keerom Regency. The purpose of this study was to determine the results of Hepatitis B and Syphilis screening in pregnant women at Kwaingga Keerom Regional Hospital. The population in this study were all patients who came for antenatal care at the Kwaingga Keerom District Hospital. The sample in this study was the blood of pregnant women used as serum with a total sample of 30 samples. The examination method is the immunochromatography method. This screening was carried out for 1 month, from January 20 to February 25, 2020. HBsAg and TP Rapid examination results obtained for HBsAg as many as 7\% positive infected with Hepatitis $B$ and $93 \%$ other negative results, and the results of TP Rapid examination were obtained results as much as $3 \%$ positive for syphilis and $97 \%$ were negative. so, from the results of HBsAg and TP Rapid examination, positive samples of hepatitis $B$ and syphilis were still obtained in pregnant women at Kwaingga Keerom Regional Hospital.
\end{abstract}

\begin{abstract}
ABSTRAK
Telah dilakukan penelitian dengan judul Skrining Penyakit Menular Pada Ibu Hamil Di Rumah Sakit Umum Daerah Kwaingga Kabupaten Keerom. Tujuan penelitian ini adalah untuk mengetahui hasil skrining Hepatitis B dan Sifilis pada ibu hamil di RSUD Kwaingga Keerom. Populasi dalam penelitian ini adalah semua pasien yang datang melakukan pemeriksaan kehamilan di RSUD Kwaingga Keerom. Sampel dalam penelitian ini adalah darah ibu hamil yang dijadikan serum dengan jumlah sampel sebanyak 30 sampel. Metode pemeriksaan adalah metode immunokromatografi. Skrining ini dilaksanakan selama 1 bulan, dari tanggal 20 Januari sampai dengan 25 Februari 2020. Hasil pemeriksaan HBsAg dan TP Rapid diperoleh hasil untuk HBsAg sebanyak 7\% positif terinfeksi penyakit Hepatitis B dan sebanyak 93\% lainnya diperoleh hasil negatif, dan hasil pemeriksaan TP Rapid diperoleh hasil sebanyak 3\% positif terinfeksi penyakit sifilis dan sebanyak 97\% lainnya diperoleh hasil negatif. jadi, dari hasil pemeriksaan HBsAg dan TP Rapid masih diperoleh sampel positif Hepatitis B dan Sifilis pada ibu hamil di RSUD Kwaingga Keerom.
\end{abstract}

Kata Kunci: Ibu hamil, Hepatitis B, Sifilis

\section{Pendahuluan}

Angka Kematian Ibu (AKI) menjadi salah satu indikator penting dari derajat kesehatan masyarakat.

Menurut World Health Organiation (WHO), dalam waktu 25 tahun yaitu dari 1990 sampai dengan 2015 diperkirakan 10,7 juta perempuan telah meninggal karena melahirkan. Angka kematian ibu di Negara Asia 
Tenggara terutama Indonesia yaitu 190 per 100.000 kelahiran hidup. Di Indonesia AKI dan angka kematian bayi (AKB) masih sangat tinggi. Pada tahun 2012, angka Kematian Ibu (AKI) mencapai 359 per 100.000 kelahiran hidup (World Health Organization, 2015).

Dalam rangka upaya percepatan penurunan AKI dan AKB, maka pada tahun 2007 Pemerintah Indonesia membuat program P4K (Program Perencanaan Persalinan dan Pencegahan Komplikasi). Salah satu kegiatan dalam program P4K adalah melakukan pelayanan antenatal yang bertujuan untuk memantau kesehatan fisik, psikologis, termasuk pertumbuhan dan perkembangan janin. Pelayanan antenatal meliputi pemeriksaan berat badan, tinggi badan, tekanan darah, $\mathrm{Hb}$, tes urin (pemeriksaan protein urin dan glukosa urin), dan tes darah (skrining penyakit Hepatitis B, sifilis, dan HIV). Salah satu pelayanan antenatal yang penting adalah skrining Hepatitis B dan sifilis pada ibu hamil diawal kehamilan atau trimester I (Kementerian Kesehatan RI, 2007).

Skrining Hepatitis B dilakukan dengan pemeriksaan HBsAg yang bertujuan untuk mendeteksi virus Hepatitis B (VHB). Skrining ini sangat penting dilakukan oleh ibu hamil untuk menghindari penularan virus secara vertikal yaitu dari ibu ke anak saat melahirkan. Menurut Sinaga et al., (2018), sebanyak 13\% dari 60 ibu hamil memiliki hasil positif terinfeksi virus Hepatitis B. Risiko penularan Hepatitis B dengan hasil pemeriksaan HBsAg positif, berbahaya terhadap janin yang dikandung ibu karena dapat mengancam keselamatan ibu dan bayinya.

Skrining lain yang penting dilakukan yaitu skrining penyakit sifilis dikarenakan sifilis akan meningkatkan risiko tertular HIV sebesar 3-5 kali. Menurut Mongan \& Sinaga (2019), dari 40 ibu hamil yang melakukan pemeriksaan di Puskesmas Kotaraja Kota Jayapura didapatkan 8\% positif terinfeksi Treponema pallidum. Risiko penularan sifilis bila tidak diobati akan menyebabkan $67 \%$ kehamilan berakhir dengan keguguran, lahir mati atau infeksi neonates dan Berat Bayi Lahir Rendah.

Pada awal kehamilan biasanya belum terlihat perubahan fisik dan gejala yang dialami oleh ibu hamil sehingga banyak ibu hamil yang tidak melakukan skrining ke dokter. Skrining masih dapat dilakukan pada kehamilan trimester ke II khususnya Skrining Hepatitis B. Hepatitis B masih dapat ditangani penularannya dari ibu ke janin dengan cara diberikan vaksinasi Hepatitis B dan HBIG pada bayi dalam waktu kurang dari 12 jam sejak dilahirkan. Sedangkan penularan sifilis dari ibu ke janin pada fase awal dapat dilakukan dengan pemberian antibiotik penisilin. Skrining Hepatitis B dan sifilis pada ibu hamil sebagai deteksi dini harus dilakukan sehingga pengobatan dan penanganan harus lebih cepat dan tepat. Berdasarkan uraian tersebut, maka peneliti tertarik untuk melakukan penelitian tentang "Skrining Penyakit Menular Pada Ibu Hamil Di Rumah Sakit Umum Daerah Kwaingga Kabupaten Keerom”.

\section{Metode Penelitian}

Jenis penelitian ini adalah deskriptif dengan uji laboratorium untuk mengetahui hasil pemeriksaan penyakit menular, dalam hal ini hepatitis B dan Sipilis pada Ibu Hamil di Laboratorium Rumah Sakit Umum Daerah Kwaingga Kabupaten Keerom. Waktu penelitian dilakukan pada 20 Januari - 25 Februari 2020. Lokasi penelitian dilakukan di Laboratorium Rumah sakit Umum Daerah Kwaingga Kabupaten Keerom. Populasi yang digunakan dalam penelitian ini adalah semua ibu hamil yang memeriksakan diri di 
Laboratorium Rumah Sakit Umum Daerah Kwaingga Keerom. Sampel yang digunakan dalam penelitian ini adalah Serum ibu hamil di RSUD Kwaingga Keerom. Teknik pengambilan sampel yang digunakan pada penelitian ini adalah Accidental Sampling yang diambil selama penelitian berlangsung. Pemeriksaan serum ibu hamil menggunakan rapid test dengan interprestasi hasil sebagai berikut :

Tabel 1 Interprestasi Hasil Pemeriksaan HBsAg dan Sifilis

\begin{tabular}{cl}
\hline Hasil & Keterangan \\
\hline Reaktif & $\begin{array}{l}\text { Terbentuk 2 garis pada area control }(\mathrm{C}) \\
\text { dan test }(\mathrm{T})\end{array}$ \\
\hline Non Reaktif & Terbentuk 1 garis pada area control $(\mathrm{C})$ \\
\hline Invalid & Tidak terdapat garis pada area control $(\mathrm{C})$ \\
\hline
\end{tabular}

Keterangan :

Reaktif : Hasil reaktif menunjukkan hasil positif

Non Reaktif : Hasil non reaktif menunjukkan hasil negative

\section{Hasil Penelitian dan Pembahasan}

Hasil pemeriksaan ibu hamil di RSUD Kwaingga Keerom dapat dilihat pada tabel di bawah ini :

Tabel 2 Data Hasil Pemeriksaan HBsAg dan TP Rapid Pada Ibu Hamil Di RSUD Kwaingga Kabupaten Keeerom

\begin{tabular}{ccccc}
\hline \multirow{2}{*}{ Trimester Kehamilan } & \multicolumn{2}{c}{ Pemeriksaan HBsAg } & \multicolumn{2}{c}{ Pemeriksaan TP Rapid } \\
\cline { 2 - 5 } & Reaktif & Non Reaktif & Reaktif & Non Reaktif \\
\hline I & - & 11 & - & 11 \\
\hline II & 2 & 14 & - & 14 \\
\hline III & - & 3 & 1 & 4 \\
\hline Total & $\mathbf{2}$ & $\mathbf{2 8}$ & $\mathbf{1}$ & $\mathbf{2 9}$ \\
\hline Persentase (\%) & $\mathbf{7}$ & $\mathbf{9 3}$ & $\mathbf{3}$ & $\mathbf{9 7}$ \\
\hline
\end{tabular}

Sumber: Data Primer (2020)

\section{Keterangan:}

Reaktif : Hasil reaktif menunjukkan hasil positif

Non Reaktif : : Hasil non reaktif menunjukkan hasil negatif

Tabel 2 menunjukan data hasil pemeriksaan HBsAg dan TP Rapid pada ibu hamil di RSUD Kwaingga Kabupaten Keerom, dimana pada hasil pemeriksaan HBsAg diperoleh 2 ibu hamil (7\%) positif terinfeksi Hepatitis B pada trimester II dan 28 sampel ibu hamil (93\%) diperoleh hasil negatif; sedangkan pada pemeriksaan TP Rapid diperoleh 1 ibu hamil (3\%) positif terinfeksi Treponema pallidum pada trimester III dan 29 sampel ibu hamil (97\%) diperoleh hasil negative.

Sampel yang digunakan dalam penelitian ini adalah darah vena yang dijadikan serum dan akan digunakan untuk pemeriksaan Hepatitis B dan Sifilis. Pemeriksaan Hepatitis B dilakukan dengan pemeriksaan HBsAg, sedangkan pemeriksaan sifilis dilakukan dengan pemeriksaan TP Rapid. Dalam penelitian ini serum yang digunakan adalah serum yang berwarna kekuning-kuningan dan tidak hemolisis. Cara untuk mendapatkan serum yang baik untuk pemeriksaan yaitu darah dibiarkan membeku dan kemudian dicentrifuge dengan kecepatan $3500 \mathrm{rpm}$ selama 10 menit. Serum yang memenuhi syarat harus tidak kelihatan merah dan keruh agar hasil pemeriksaan yang didapatkan lebih akurat. Menurut Gandasoebrata 
(2013), serum yang berwarna kemerahan tidak dapat digunakan untuk pemeriksaan karena dapat mempengaruhi keakuratan hasil pemeriksaan.

Hasil pemeriksaan HBsAg pada Tabel 2 menunjukan jumlah ibu hamil yang melakukan skrining HBsAg sebanyak 30 orang (100\%), dengan hasil positif HBsAg sebanyak 2 orang (7\%). Hasil tersebut memang hanya sebagian kecil dikarenakan ibu hamil yang berada di lingkungan RSUD Kwaingga Keerom sering melakukan pemeriksaan kehamilan rutin dan mendapatkan vaksin atau imunisasi Hepatitis B sehingga ibu hamil tersebut memiliki antibodi terhadap Virus Hepatitis B. Hasil penelitian ini didukung oleh penelitian Sinaga et al., (2018), yang mengatakan ibu hamil yang melakukan pemeriksaan di Puskesmas Sentani Kota dan RSMI cukup rendah dikarenakan telah mendapatkan vaksin atau imunisasi Hepatitis B ataupun memiliki antibodi terhadap virus Hepatitis B.

Berdasarkan Tabel 2 ibu hamil yang memiliki hasil positif sebanyak 2 orang (7\%) yang berada pada usia kehamilan trimester II. Hal ini disebabkan karena pada awal kehamilan belum terlihat perubahan fisik dan gejala yang dialami oleh ibu hamil sehingga banyak ibu hamil yang tidak melakukan skrining diawal kehamilan Pada usia kehamilan ini masih dapat dilakukan penanganan pada ibu hamil dengan memberikan vaksin Imunoglobulin Hepatitis B (HBIG) untuk memperkuat sistem imunitas dan mencegah perkembangan Virus dalam tubuh. Jika saat ibu hamil melakukan pemeriksaan HBsAg dan dinyatakan Reaktif (Positif) terinfeksi Virus Hepatitis B, maka akan diberikan vaksin HBIG yang memperkuat sistem imunitas tubuh guna mencegah perkembangan virus dalam tubuh. Apabila dalam kasus yang lebih parah (viral load), maka dokter akan memberikan obat antivirus guna mencegah perkembangan Virus Hepatitis B pada janin (CDC, 2010).

Pada hasil pemeriksaan TP Rapid (yang ditunjukkan pada Tabel 2) ibu hamil yang positif sebanyak 1 orang (3\%) dari 30 responden (100\%). Dalam penelitian ini didapatkan ibu hamil yang terinfeksi Treponema pallidum di RSUD Kwaingga Keerom sangat rendah. Hal ini kemungkinan besar disebabkan karena ibu hamil telah mendapatkan pemeriksaan kesehatan diawal kehamilan dan penyuluhan kesehatan tentang penyakit menular seperti penyakit sifilis yang disebabkan oleh seks bebas. Hasil penelitian ini didukung oleh penelitian (Mongan \& Sinaga, 2019) yang mengatakan bahwa hasil pemeriksaan TP Rapid rendah di Puskesmas Kotaraja dikarenakan ibu hamil telah melakukan pemeriksaan kesehatan pada awal kehamilan, melakukan promosi kesehatan atau penyuluhan tentang penyakit sifilis, serta menjaga kebersihan dan cara hidup sehat. Penyakit sifilis merupakan penyakit yang berbahaya karena dapat menyerang seluruh organ tubuh. Oleh karena itu, setiap ibu hamil sangat dianjurkan untuk memeriksakan kesehatan janin yang dikandungnya karena pengobatan yang cepat dan tepat dapat menghindari terjadina penularan penyakit dari ibu ke anak.

Berdasarkan Tabel 2 ibu hamil yang terinfeksi Treponema pallidum sebanyak 1 orang (3\%) yang berada pada usia kehamilan trimester III. Usia kehamilan ini menjadi sangat berbahaya apabila ibu hamil terinfeksi Treponema pallidum karena dapat menularkan ke janin yang dikandungnya melalui plasenta atau melalui kontak dengan luka selama proses kelahiran. Penanganan yang dapat dilakukan adalah dengan terapi injeksi benzil benzatin penicillin $G$ yang diberikan secara intramuscular dengan resep dokter. Menurut CDC (2010), pemberian terapi penisilin pada ibu hamil adalah untuk menangani penyakit ibu, mencegah transmisi 
pada janin dan menangani penyakit sifilis yang terjadi pada janin. Penyakit sifilis pada ibu hamil yang tidak diobati dapat mengakibatkan keguguran, bayi lahir premature dan sifilis kongenital.

Pada penelitian ini tidak ditemukan sampel dengan hasil positif keduanya baik HBsAg maupun TP Rapid. Hanya ditemukan hasil positif HBsAg pada satu sampel dan begitupula sebaliknya pada pemeriksaan TP Rapid. Berdasarkan hasil observasi yang dilakukan dengan responden sebanyak 16,70\% ibu hamil yang memiliki hasil positif HBsAg belum pernah mendapatkan vaksin atau imunisasi Hepatitis B dikarenakan lokasi rumah yang berada jauh dari pusat pelayanan kesehatan dan kurangnya pemahaman mengenai penyakit Hepatitis B. ibu hamil yang tidak pernah di vaksin atau imunisasi Hepatitis B tidak memiliki antibodi di dalam tubuhnya untuk melawan Virus Hepatitis B sehingga dapat dengan mudah terinfeksi Virus Hepatitis B. Menurut penelitian yang dilakukan Pratono (2016), melaporkan bahwa ibu hamil yang tidak pernah diimunisasi Hepatitis B berpeluang $73 \%$ lebih besar terinfeksi daripada ibu hamil yang pernah di imunisasi Hepatitis B. Faktor lain yang dapat menyebabkan ibu hamil terinfeksi Hepatitis B yaitu tinggal serumah dengan penderita Hepatitis B terlebih lagi jika suami dari ibu hamil yang terinfeksi sehingga penularan dapat melalui hubungan seksual. Sedangkan untuk responden ibu hamil yang memiliki hasil TP Rapid positif tidak mengetahui bahwa dirinya terinfeksi Treponema pallidum karena kurangnya pengetahuan dan informasi yang didapatkan tentang cara penularan dan gejala yang akan timbul. Kemungkinan besar ibu hamil dapat terinfeksi Treponema pallidum melalui hubungan seksual dengan orang yang telah terinfeksi Treponema pallidum. Menurut Chandra (2013), sebagian besar kasus sifilis dapat ditularkan melalui kontak seksual, tetapi juga dapat menyebar secara kongenital (pada kehamilan melalui transplasenta atau selama persalinan).

Faktor risiko ibu hamil dengan hasil HBsAg positif 90\% akan menularkan kepada janin melalui plasenta, kontaminasi dengan darah pada waktu persalinan, dan melalui air susu ibu (ASI) pada masa laktasi. Menurut Radji (2015), virus Hepatitis B dapat menembus plasenta, sehingga terjadi Hepatitis virus in utero dengan akibat janin lahir mati atau janin mati pada periode neonatal. Sedangkan faktor risiko ibu hamil dengan hasil positif TP Rapid dapat menularkan kepada janin melalui plasenta atau pada saat persalinan. Infeksi sifilis pada kehamilan disebut sifilis kongenital. Menurut Chandra (2013), pada wanita dengan sifilis didapatkan akan berdampak kepada janin sehingga dapat menyebabkan kematian janin, kematian neonatus, kelahiran premature, serta berat badan lahir rendah.

Skrining penyakit Hepatitis B dan sifilis sangat penting dilakukan oleh ibu hamil untuk mengurangi angka kematian ibu dan bayi yang disebabkan oleh penyakit menular. Ibu hamil harus rutin melakukan pemeriksaan kesehatan dengan tujuan untuk mencegah dan mengatasi masalah kehamilan, untuk membantu masalah gizi, dan cara menjaga diri agar tetap sehat dalam masa hamil dan membantu ibu hamil dan keluarganya untuk mempersiapkan kelahiran bayi. Pemeriksaan kesehatan paling sedikit dilakukan selama 4 kali selama kehamilan, satu kali pada trimester I, satu kali pada trimester II dan dua kali pada trimester III. Sesuai dengan standar asuhan pelayanan pemeriksaan kesehatan yang wajib dilakukan oleh ibu hamil antara lain timbang berat badan, ukur tekanan darah, ukur tinggi fundus urteri, pemberian tablet $\mathrm{Fe}$, pemberian imunisasi Tetanus Toxoid, pemeriksaan Hb, pemeriksaan pemeriksaan protein dan reduksi urin. Oleh karena 
itu, setiap ibu hamil sangat dianjurkan untuk memeriksakan kesehatan janin yang dikandungnya. Pengobatan yang cepat dan tepat dapat menghindari terjadinya penularan penyakit dari ibu ke janin.

\section{Kesimpulan}

Ditemukan ibu hamil yang terinfeksi penyakit menular, dalam hal ini Hepatitis B dan Sipilis, penanganan lebih lanjut harus segera dilakukan untuk dapat membantu ibu dan bayinya.

\section{Daftar Pustaka}

CDC. (2010). Sexually Transmitted Disease. http://www.cdc.gov/std/pregnancy.htm

Chandra, B. (2013). Kontrol Penyakit Menular Pada Manusia. EGC.

Gandasoebrata, R. (2013). Penuntun Laboratorium Klinik. Dian Rakyat.

Kementerian Kesehatan RI. (2007). Pedoman Tatalaksana dan Rujukan Hepatitis B. Direktorat PP.

Ko. (n.d.).

Mongan, E., \& Sinaga, H. (2019). Pemeriksaan Infeksi Menular Seksual Pada Ibu Hamil Di Puskesmas Kotaraja Kota Jayapura. Global Health Sience, 4(2), 59-63.

Pratono, A. (2016). Faktor Kejadian Hepatitis B Pada Ibu Hamil Di Wilayah DKI Jakarta Tahun 2016. Jurnal Kesmas Indonesia, 11(2), 106-115.

Radji, M. (2015). Imunologi dan Virologi. PT ISFI.

Sinaga, H., Latif, I., \& Pangulu, N. (2018). Pemeriksaan Hepatitis B Surface Antigen (HBsAg) dan Anti HBS Pada Ibu Hamil Sebagai Skrining Penularan Hepatitis B. Jurnal Riset Kesehatan, 7(2), 80-84.

World Health Organization. (2015). Angka Kematian Ibu (AKI) dan Angka Kematian Bayi. https://www.unicef.org/indonesia/id/A5_B_Ringkasan_Kajian_Kesehatan_REV.pdf 